\title{
PRODUCTION AND MARKETING CONSTRAINTS OF SMALL STOCK FARMING: EVIDENCE FROM LIMID AND NON-LIMID FARMERS IN BOTETI SUB-DISTRICT, BOTSWANA
}

\author{
Agnes Binge $^{1 \bowtie}$, Patience Mshenga ${ }^{1}$, Keneilwe Kgosikoma ${ }^{2}$ \\ ${ }^{1}$ Egerton University, Kenya \\ ${ }^{2}$ Botswana University of Agriculture and Natural Resources, Botswana
}

\begin{abstract}
The majority of the rural population in Botswana keep small stock as a source of livelihood. However, small stock farmers face many constraints which impede maximization of their production and returns. Yet there is dearth of information on the major challenges they face. This study was intended to give an overview of major production and marketing constraints faced by small stock farmers; and to identify factors influencing farmers' participation in the LIMID program in Boteti sub-district, Botswana. Multistage sampling technique was used to collect data from 150 respondents selected randomly. Descriptive statistics, factor analysis and probit regression analytical techniques were used in data analysis. Factors that significantly influenced effective participation of small stock producers in the program are positive perception of the program, distance to a LIMID office, distance to a nearby cattle post, and household income. Production constraints included predators, theft, pasture scarcity, natural disasters, water scarcity and lack of transport. Further, marketing constraints were reported to be low prices, delayed payments from the government, poor roads and lack of marketing information. The study provides a basis for policy formulation to improve the effectiveness of smallholder farmers and develop measures required to help them improve their productivity.
\end{abstract}

Keywords: small stock, smallholder, LIMID, rural dwellers, cattle post, constraints

\section{INTRODUCTION}

The agricultural sector is vital to the economy of Botswana. It contributes $2.4 \%$ to Gross Domestic Product (GDP) of the country, with livestock production contributing $80 \%$ to agricultural GDP (USDA, 2017). Many Batswana depend on livestock as a source of livelihood mainly because of the climatic conditions in the country which are favorable to livestock production but detrimental to crop production. The foregoing makes livestock a central economic activity in rural areas, providing sustainable employment and generating income for many poor households (UNESCO, 2012). In recent past, small stock production has gained much attention from Botswana government, especially as regards rural economies. Consequently, the government introduced programs to enhance small stock production. One such program is LIMID (Livestock Management and Infrastructure Development), introduced to provide funding and augment farmers' efforts in keeping small stock, thereby improving their efficiency and livelihoods.

On the other hand, small stock farmers still face several constraints impeding the efforts they make to maximize farm production and returns. Empirical review showed that small stock farmers are faced with production challenges. According to Temoso et al. (2015),

\footnotetext{
$凶$ Agnes Binge, Msc, Department of Agricultural Economics and Agribusiness Management, Egerton University, P.O. Box 536, 20115 Egerton, Kenya, e-mail: agnes.binge@gmail.com, https://orcid.org/0000-0003-0787-9452
} 
Binge, A., Mshenga, P., Kgosikoma, K. (2019). Production and marketing constraints of small stock farming: evidence from limid and non-limid farmers in Boteti sub-district, Botswana. J. Agribus. Rural Dev., 3(53), 195-201. http://dx.doi.org/10.17306/ J.JARD.2019.01197

competition with wildlife is a major concern, as sheep and goats are normally a prey for wild animals. The occurrence of diseases and pests infestation also poses a challenge (Berihu et al., 2016). A study by Druilhe and Barreiro-Hurle (2012) posited that lack of access to credit by farmers was an impediment. Literature also revealed that smallholder farmers face marketing constraints. Shapi (2017) reported the lack of effective markets as a constraint faced by smallholder farmers. Purchase of small stock at very low prices is another major concern (Bahta et al., 2013).

Nonetheless, there is limited empirical literature on the constraints specifically faced by smallholder, small stock farmers in Boteti sub-district of Botswana. The factors influencing farmers' participation in LIMID also remain unknown. Therefore, the objectives of the study were to identify the main marketing and production constraints encountered by small stock producers as well as to identify the factors influencing effective participation of small stock producers in the program in Boteti subdistrict. Owing to the fact that many rural dwellers depend on small stock for a living, there is need to analyze the challenges they face. Having a grasp of challenges encountered by farmers is expected to prompt appropriate interventions for better production and, in turn, enhance farmers' livelihoods.

\section{METHODOLOGY}

\section{Study area}

The study was conducted in Central District of Botswana, specifically the Boteti sub-district. The Central District is the country's largest district in terms of both area and population. Boteti is located at longitudes between $23^{\circ} 53^{\prime}$ and $26^{\circ} 17^{\prime}$ east and at latitudes between $20^{\circ} 12^{\prime}$ and $22^{\circ} 24^{\prime}$ south. It is affected by extreme temperatures: cold winters go below $6^{\circ} \mathrm{C}$ and hot summers reach a high of $35.2^{\circ} \mathrm{C}$ on average. The district experiences variable rainfall and drought occurrences, thereby rendering Boteti unsuitable for arable production (Sebego et al., 2017). The main source of livelihood in Boteti is livestock production.

\section{Research design and sample size}

The study used a cross-sectional household survey. The targeted population for the study were smallholder small stock farmers. A multistage sampling procedure was used to select the respondents. In the first stage, purposive sampling of the Central District was done because it has the largest number of sheep and goats in the whole country, thereby giving the researcher an advantage of attaining the required sample. In the second stage, Boteti sub-district was purposively chosen as the agro-ecology of Boteti gives it an advantage of having more small stock producers. In the third stage, 3 villages with the largest population, Rakops, Mopipi and Xhumo, were purposively selected because they were located close to each other and due to time and budget constraints. In the last stage, the sub-samples of LIMID participants and non-participants were selected using simple random sampling. The respondents were picked proportionally to the size of the villages. Data was collected using a face-to-face questionnaire administered to 150 randomly selected households

The population of the beneficiaries and non-beneficiaries was not known. Therefore, to determine the sample size, a formula by Cochran (1963) was used with:

$$
n=\frac{p q Z^{2}}{E^{2}}
$$

where:

$$
\begin{aligned}
& n \text { - sample size } \\
& p \text { - population proportion } \\
& q \text { - weighted variable, } q=1-p \\
& E \text { - allowable error, } E=0.08 \\
& p=0.5 \text { since } q=1-0.5=0.5 \\
& Z \text { - standard deviation, at } 95 \% \text { confidence interval, } \\
& \quad Z=1.96 .
\end{aligned}
$$

\section{Analytical framework}

Descriptive statistics were used to analyze the data on the constraints encountered by small stock farmers. Factor analysis was used to summarize the perceptions regarding participation in LIMID. Factor analysis is needed in reducing the number of variables into few clusters for better interpretation (Yong and Pearce, 2013). The factors retained were based on the Kaiser's criterion which suggests that all factor loadings with an eigenvalue above 1 should be considered, as adopted in a study by Kweyu and Ngare (2013). Furthermore, Kaiser Meyer-Olkin (KMO) measure was estimated for the items in order to appraise the suitability of the factor analysis method. Boohene et al. (2012) stated the KMO value ranges between 0 and 1 , so the closer the value is to 1 , the more significant is the correlation between the variables. All the factors retained had a KMO of more 
Binge, A., Mshenga, P., Kgosikoma, K. (2019). Production and marketing constraints of small stock farming: evidence from limid and non-limid farmers in Boteti sub-district, Botswana. J. Agribus. Rural Dev., 3(53), 195-201. http://dx.doi.org/10.17306/ J.JARD.2019.01197

than 0 ; they were later used as independent variables for further analysis. Probit model was used in analyzing the factors that influenced the rural farmers' decision to participate in small stock production.

Probit modeling was adopted and modified based on Verbeke et al. (2000):

$$
Y_{i}^{*}=\beta_{0}+\sum_{k-1}^{K} \beta_{k} \chi_{k i}+\mu_{i}
$$

where:

$i$-denotes the number of the respondent

$Y_{i}^{*}$-is the participation decision $\left(Y_{i}^{*}=1\right.$ for LIMID participants; $Y_{i}^{*}=0$ otherwise)

$\chi_{i}-$ is the explanatory variable likely to determine the probability of participating in LIMID

$\beta_{k}$-indicates the effect of explanatory variable on the dependent variable

$\mu_{i}$-is the error term with zero mean and constant variance.

\section{RESULTS AND DISCUSSION}

\section{Selected socioeconomic dimensions of small stock farmers}

The descriptive statistics of the farmers' socioeconomic characteristics are presented in Table 1. The results show that there were more female than male farmers who keep small stock (57\%). This is consistent with Moreki et al. (2010) who found that women own more goats than men who normally have extensive resources, thereby being in a better position to purchase more valuable livestock like cattle. Regarding the main sources of income for the farmers, the results show that their first income source was small stock farming. Livestock is an indispensable source of income, with sheep and goats being of utmost importance (Ibrahim et al., 2013). When it comes to education levels, the study found that most farmers (37\%) attended junior schools and only a few attended tertiary schools $(4 \%)$. The table also shows that most small stock farmers $(63 \%)$ are not married (are single, widowed or divorced).

\section{Production constraints that impede farmers from maximizing their production}

There are several production constraints that producers are facing, as reported in Table 2. The first major production constraint are predators like jackals, foxes, lions and dogs. The constraint is common amongst all
Table 1. Selected socioeconomic characteristics of small stock farmers

\begin{tabular}{lcc}
\hline \multicolumn{1}{c}{ Variable } & Frequency & $\%$ \\
\hline Main source of income & 63 & 42 \\
small stock & 8 & 5 \\
other on-farm & 37 & 25 \\
off-farm employment & 33 & 22 \\
government schemes & 9 & 6 \\
own business & & \\
Marital status & 55 & 37 \\
married & 80 & 53 \\
single & 4 & 3 \\
divorced & 11 & 7 \\
widowed & & 57 \\
Education level & 36 & 24 \\
no formal education & 38 & 25 \\
primary school & 55 & 37 \\
junior school & 15 & 10 \\
high school & 64 & 43 \\
tertiary institution & & \\
Gender distribution & & \\
female & & \\
male & & \\
\hline
\end{tabular}

Source: own elaboration based on data collected.

Table 2. Production constraints faced by small stock farmers

\begin{tabular}{lc}
\hline \multicolumn{1}{c}{ Challenges } & Number of cases (\%) \\
\hline Predators & 90.7 \\
Theft & 82.7 \\
Diseases & 78.0 \\
Insufficient financial support & 71.3 \\
Pasture scarcity & 45.3 \\
Inadequate extension services & 23.3 \\
Natural disaster & 20.0 \\
Water scarcity & 18.0 \\
Transport & 16.0 \\
\hline
\end{tabular}

Source: own elaboration based on data collected. 
Binge, A., Mshenga, P., Kgosikoma, K. (2019). Production and marketing constraints of small stock farming: evidence from limid and non-limid farmers in Boteti sub-district, Botswana. J. Agribus. Rural Dev., 3(53), 195-201. http://dx.doi.org/10.17306/ J.JARD.2019.01197

the villages surveyed. Mosalagae and Mogotsi (2013) reported that pastoral farmers in Botswana lose livestock due to predation. Theft was ranked the second important constraint. In Kgalagadi south, Botswana, pastoral households reported to be facing the problem of theft (Mosalagae and Mogotsi, 2013). Ranked third in the area were livestock diseases. Pest and diseases are amongst the major agricultural productivity challenges (Phiri et al., 2012). Also, insufficient financial support service was noted as another production constraint. Druilhe and Barreiro-Hurle (2012) posited that in subSaharan African countries, farmers face several challenges which include lack of access to credit. Furthermore, feed unavailability was another limiting factor in small stock production with farmers having ranked pasture scarcity as the sixth major constraint they face in production.

Inadequate extension services were another constraint indicated by the respondents. Ahmed and Egwu (2014) found inadequate extension services to be one of major constraints for sheep farming. Natural disasters were also identified as a constraint for the farmers. Some small stock farmers lose their animals to nature's misfortunes like droughts, floods and sometimes animals being struck by lightning.

\section{Marketing constraints faced by small stock farmers}

Small stock farmers reported to be facing numerous marketing constraints as presented in Table 3 below. Lack of markets was ranked first among the marketing constraints. Farmers indicated that they normally face a problem of identifying a proper market to send their produce to since the government has become a major buyer. The government normally buys small stock with the main purpose of supplying it to the beneficiaries of public programs to encourage their participation in livestock farming. Shapi (2017) reported that lack of access to effective and efficient markets is one of the factors that impede the sale of smallholder farmers' produce. Another marketing constraint were low prices offered at the market place. The results are substantiated by Bahta et al. (2013) who found that in Botswana, farmers complain of low prices that traders offer in exchange of their livestock.

The lack of transport was rated as the third marketing constraint. Farmers reported that they lack transport to carry their small stock to nearby lucrative markets
Table 3. Marketing constraints faced by small stock farmers

\begin{tabular}{lc}
\hline \multicolumn{1}{c}{ Constraints } & Number of cases (\%) \\
\hline Lack of market & 88.7 \\
Low prices & 87.3 \\
Lack of transport & 66.0 \\
Delayed payments & 43.3 \\
from the government & \\
Poor roads & 30.7 \\
Lack of information & 28.0 \\
\hline
\end{tabular}

Source: own elaboration based on data collected.

and hence they sell it at very low prices to buyers in the sub-district. Meanwhile, poor roads were ranked fifth. Poor roads were also identified to be some of the challenges that are faced by farmers in Namibia when they are transporting their goods (Hangara et al., 2011). The least important marketing constraint was lack of information, as shown in Table 3. Access to market information is vital to smallholder farmers as they get to know available markets and prices.

\section{Factors influencing the rural farmers' decision to participate in LIMID}

As shown in Table 4, the relationship between participating in LIMID and gender is negative, implying that being male decreases the probability of keeping small stock by $38.8 \%$. This finding agrees with Assa et al. (2014) who stated that more women participated in small ruminant production as compared to their male counterparts. An increase in the age of the respondent by one year decreases the chances of participating in the program by $0.8 \%$. The older the individuals, the less they are likely to apply for the program, knowing that they would be unable to manage small stock due to old age. On the other hand, young people will opt to keep small stock, knowing that they are capable of staying at cattle post and herd their sheep or goats. An increase in age makes farmers quit active farming; hence, young people need to be encouraged to engage in the farming business (Akpan and Udoh, 2016).

Results on the years of schooling indicate that an extra year of schooling decreases by $2 \%$ the probability of farmers participating in the program. The possible explanation is that the more people get educated, 
Binge, A., Mshenga, P., Kgosikoma, K. (2019). Production and marketing constraints of small stock farming: evidence from limid and non-limid farmers in Boteti sub-district, Botswana. J. Agribus. Rural Dev., 3(53), 195-201. http://dx.doi.org/10.17306/ J.JARD.2019.01197

Table 4. Description of variables used in the study

\begin{tabular}{lc}
\hline \multicolumn{1}{c}{ Variable } & Description \\
\hline Gender of the farmer & $1=$ male, $0=$ female \\
Access to extension services & Number of contacts \\
Distance to LIMID office & $\mathrm{km}$ \\
Age of the farmer & years \\
Distance to water source & $\mathrm{km}$ \\
Farm size & ha \\
Years of schooling of the farmer & years \\
Distance to input market & $\mathrm{km}$ \\
Farming as the main occupation & $1=$ full-time, $0=$ part-time \\
Household income (000) & BWP (Botswana currency) \\
Herd size & Number \\
Distance to nearby cattle post & km \\
Main labor source & $1=$ family, $0=$ hired \\
Perceptions (1-6) & $1=$ agree, $2=$ neutral, \\
\end{tabular}

Source: own elaboration based on data collected.

the more they are likely to get better jobs and be lifted from poverty compared to those who are not educated. The perception about being accepted into the program is statistically significant in influencing participation in the program. A positive perception will increase the chances of participating in the program by $9.2 \%$. A positive perception encouraged the resource-poor to apply for the program, knowing that they will be accepted for funding. LIMID specifically targets the vulnerable groups like women and the youth. This result is similar to Charatsari et al. (2013) who noted that more females are willing to take part in agricultural programs.

A positive relation exists between household income and participation, indicating that an increase in household income by USD 1 will increase participation in the program by $3.3 \%$. Farmers with higher income are able to sustain their projects as they can buy inputs like supplementary feeds and drugs when the ones given by the government are finished. Nahayo et al. (2017) found that off-farm income makes the farmers more likely to participate in the program as off-farm income helps financing program activities. An increase in the use of
Table 5. Factors influencing the rural farmers' decision to participate in LIMID

\begin{tabular}{|c|c|c|c|c|}
\hline Variable & $\begin{array}{l}\text { Marginal } \\
\text { effects }\end{array}$ & $\begin{array}{l}\text { Std. } \\
\text { err. }\end{array}$ & $z$ & $P>z$ \\
\hline Gender of the farmer & -0.388 & 0.0923 & -4.18 & 0.000 \\
\hline $\begin{array}{l}\text { Access to extension } \\
\text { services }\end{array}$ & 0.063 & 0.106 & 0.60 & 0.549 \\
\hline $\begin{array}{l}\text { Distance to LIMID } \\
\text { office }\end{array}$ & -0.005 & 0.003 & -1.83 & 0.068 \\
\hline Age of the farmer & -0.008 & 0.004 & -2.11 & 0.035 \\
\hline Distance to water source & 0.057 & 0.041 & 1.39 & 0.163 \\
\hline Farm size & 0.006 & 0.009 & 0.66 & 0.507 \\
\hline $\begin{array}{l}\text { Years of schooling of } \\
\text { the farmer }\end{array}$ & -0.020 & 0.011 & -1.75 & 0.080 \\
\hline Distance to input market & 0.001 & 0.001 & -1.35 & 0.176 \\
\hline $\begin{array}{l}\text { Farming as the main } \\
\text { occupation }\end{array}$ & 0.032 & 0.054 & 0.60 & 0.546 \\
\hline $\begin{array}{l}\text { Household income } \\
(000)\end{array}$ & 0.033 & 0.020 & 2.16 & 0.030 \\
\hline Herd size & 0.002 & 0.002 & 1.03 & 0.304 \\
\hline $\begin{array}{l}\text { Distance to nearby } \\
\text { cattle post }\end{array}$ & 0.069 & 0.041 & 1.68 & 0.094 \\
\hline Main labor source & -0.226 & 0.109 & -2.08 & 0.037 \\
\hline $\begin{array}{l}\text { Perception 1: impact on } \\
\text { household welfare }\end{array}$ & -0.039 & 0.052 & -0.74 & 0.461 \\
\hline $\begin{array}{l}\text { Perception 2: accept- } \\
\text { ance into the program }\end{array}$ & 0.092 & 0.047 & 1.93 & 0.054 \\
\hline $\begin{array}{l}\text { Perception 3: transpar- } \\
\text { ency in selection }\end{array}$ & 0.095 & 0.112 & -0.84 & 0.399 \\
\hline $\begin{array}{l}\text { Perception 4: sufficiency } \\
\text { of the funding }\end{array}$ & 0.059 & 0.123 & 0.48 & 0.630 \\
\hline $\begin{array}{l}\text { Perception 5: adequacy } \\
\text { of extension services }\end{array}$ & -0.057 & 0.058 & -0.96 & 0.336 \\
\hline $\begin{array}{l}\text { Perception 6: ease of ap- } \\
\text { plication for funding }\end{array}$ & 0.071 & 0.065 & -1.09 & 0.274 \\
\hline $\begin{array}{l}\text { Number of } \\
\text { observations }\end{array}$ & 150 & & & \\
\hline LR $\operatorname{chi}^{2}$ (15) & 42.74 & & & \\
\hline Prob $>$ chi $^{2}$ & 0.0022 & & & \\
\hline Log likelihood & -70.614035 & & & \\
\hline Pseudo $\mathbf{R}^{2}$ & 0.2604 & & & \\
\hline
\end{tabular}

Source: own elaboration based on data collected. 
Binge, A., Mshenga, P., Kgosikoma, K. (2019). Production and marketing constraints of small stock farming: evidence from limid and non-limid farmers in Boteti sub-district, Botswana. J. Agribus. Rural Dev., 3(53), 195-201. http://dx.doi.org/10.17306/ J.JARD.2019.01197

hired labor will decrease the probability of someone applying for LIMID funding by $22.6 \%$ because they cannot afford the wage rate of their employees. Finally, an increase in the distance to extension office decreases by $0.5 \%$ the probability of people participating in the program. The possible explanation could be that people living far away from the office are reluctant to visit it and apply because of the long distance.

\section{CONCLUSION AND RECOMMENDATIONS}

The study results revealed that small stock farmers are faced with numerous marketing and production constraints which impede them from maximizing their production. These constraints need to be addressed. The major production constraints were pasture scarcity, natural disasters, lack of proper markets, predators, theft, pests and diseases, insufficient financial support, inadequate extension services, water scarcity and lack of transport. Marketing constraints were reported to be low prices, delayed payments from the government, poor roads and lack of marketing information. In order for the small stock projects to benefit and impact even more livelihoods, marketing constraints (especially the low prices which are a concern to many smallholder farmers) should be addressed by the government. There should be a law that is imposed to set a minimum price for buying and selling small stock so that both small stock farmers and buyers can benefit. Farmers must also be trained in keeping small stock and be taught proper management and the importance of using supplementary feeds and drugs to protect their animals against diseases. Workshops would be of great benefit to farmers if delivered by extension workers in each village. This would help in improving production capacity and, hence, in attaining better profits. People must be trained on livestock production to encourage their participation in the program.

\section{SOURCE OF FINANCING}

African Economic Research Consortium (AERC)

\section{ACKNOWLEDGEMENT}

The author's special gratitude goes to the African Economic Research Consortium (AERC) who enabled this study by funding the project.

\section{REFERENCES}

Aganga, A. O., Aganga, A. A. (2015). Quality Assurance in Goat Meat Production for Food Safety in Botswana. Asian J. Biol. Sci., 8(2), 51-56.

Ahmed, A., Egwu, G. O. (2014). Management Practices and Constraints of Sheep Farmers in Sokoto State, Nigeria. Int. J. Sci. Technol., 3(2), 735-748.

Akpan, S. B., Udoh, E. (2016). Farmers' Decision to Participate In Government Agricultural Programmes in a Volatile Political Environment: A Case Study of Farmers in The South-South Region Of Nigeria. J. Agric. Soc.-Econ. Sci., 5(43), 135-147.

Assa, M. M., Maonga, B. B., Mapemba, L. D. (2014). Determinants of Keeping Small Ruminants and Non-ruminant Livestock in Malawi: A Simulated Maximum Likelihood Multivariate Probit. Agrekon, 53(4), 123-135.

Bahta, S., Baker, D., Podisi, B., Marobela, O. (2013). Competitive smallholder livestock in Botswana: Results of a livestock value chain survey in the Central district of Botswana. Nairobi: International Livestock Research Institute.

Berihu, M., Berhane, G., Gebrechiristos, S. (2016). Feeding and Management Practices of Free Range Goat Production in Tahtay Koraro District Ethiopia. College of Veterinary Medicine and Agriculture. Am. J. Soc. Manag. Sci., 6(2), 40-47.

Boohene, R., Marfo-Yiadom, E., Yeboah, M. A. (2012). An empirical Analysis of the Effect of Entrepreneurial Orientationon Firm Performance of Auto Artisans in the Cape Coast Metropolis. Dev. Count. Stud., 2(9), 1-8.

Charatsari, C., Istenič, C. M., Lioutas, E. D. (2013). "I'd like to participate, but...": Women farmers' scepticism towards agricultural extension/education programs. Dev. Pract., 23(1), 511-525.

Cochran, W. G. (1963). Sampling Techniques (2nd ed.). New York: John Wiley and Sons.

Druilhe, Z., Barreiro-Hurlé, J. (2012). Fertilizer subsidies in sub-Saharan Africa. ESA Working paper No. 12, 04 July 2012. Agricultural Development Economics Division Food and Agriculture Organization of the United Nations.

Hangara, G. N., Teweldemedhin, M. Y., Groenewald, I. B. (2011). Measuring factors that can influence cattle supply response to the market in Namibia: A Case of Omaheke communal farmers. J. Agric. Exten. Rural Dev., 3(8), 141-146.

Ibrahim, A., Shiwei, X., Wen, Y. (2013). The Impact of Social Factors of Rural Households on Livestock Production and Rural Household Income in White Nile State of Sudan. Int. J. Agric. Food Res., 2(4), 1-13.

Kelebe, H. E., Ayimut, K. M., Berhe, G. H., Hintsa, K. (2017). Determinants for adoption decision of small scale biogas 
Binge, A., Mshenga, P., Kgosikoma, K. (2019). Production and marketing constraints of small stock farming: evidence from limid and non-limid farmers in Boteti sub-district, Botswana. J. Agribus. Rural Dev., 3(53), 195-201. http://dx.doi.org/10.17306/ J.JARD.2019.01197

technology by rural households in Tigray, Ethiopia. Energy Econ., 66, 272-278.

Morgan, K. L., Briggs, A. C., Degner, R. L., Stevens III, T.J (2004). A Probit Model Analysis of Factors Affecting Consumption of Fresh Sweet Corn in Major U.S. Markets. Southern Agricultural Economics Association Annual Meetings February 18, 2004, Oklahoma, USA.

Kweyu, M., Ngare, P. (2013). Factor Analysis of Customers Perception of Mobile Banking Services in Kenya. JETEMS, 5(1), 1-8.

Moepeng, P. T., Tisdell, C. A. (2008). The Pattern of Livelihoods in a Typical Rural Village Provides New Perspectives on Botswana's Development: Social Economics, Policy and Development Working Papers 52. University of Queensland.

Moreki, J. C., Mokokwe, J., Keboneilwe, D., Koloka, O. (2010). Evaluation of the livestock management and infrastructure development support scheme in seven districts of Botswana. Retrieved from: http://www.lrrd.org/lrrd22/5/ more22087.htm

Mosalagae, D., Mogotsi, K. (2013). Caught in a sandstorm: an assessment of pressures on communal pastoral livelihoods in the Kalahari Desert of Botswana. Pastor. Res. Policy Pract., 3(18), 1-20.

Nahayo, A., Omondi, M. O., Xu-hui, Z., Lian-qing, L., Genxing, P., Joseph, S. (2017). Factors influencing farmers' participation in crop intensification program in Rwanda. J. Integ. Agric., 16(6), 1406-1416.
Phiri, M. A. R., Chilonda, P., Manyamba, C. (2012). Challenges and Opportunities for Raising Agricultural Productivity in Malawi. Int. J. Agric. Forest., 2(5), 210-224.

Sebego, R. J., Atlhopheng, J. R., Chanda, R., Mulale, K., Mphinyane, W. (2017). Land use intensification and implications on land degradation in the Boteti area: Botswana. Afric. Geogr. Rev. Retrieved from: http://dx.doi.org/1 $0.1080 / 19376812.2017 .1284599$

Shapi, M. K. (2017). Contemporary Challenges Facing the Small Farmers in the Green Scheme Projects in Namibia. Sustain. Agric. Res., 6(3), 1-13.

Temoso, O., Hadley, D., Villano, R. (2015). Technical efficiency and technological gaps for extensive beef farms in Botswana : A stochastic meta-frontier approach. Coference paper for annual AARES.Rotoa, New Zealand 10-13 February 2015.

UNESCO (2012). Report on Livestock Value Chains in Eastern and Southern Africa . Eighth Session of the Committee on Food Security and Sustainable Development 19-21 November. Addis Ababa, Ethopia.

USDA (2017). Agricultural Information Network: Botswana. Agricultural Economic Fact Sheet Report. 20 August.

Verbeke, W., Ward, R., W.,Viaene, J. (2000). Probit analysis of fresh meat consumptionin Belgium: Exploring BSE and television communication impact. Agribusiness, 16(2), 215-234.

Yong, A. J., Pearce, S. (2013). A Beginner's Guide to Factor Analysis: Focusing on Exploratory Factor Analysis. Tutor. Quant. Method. Psych., 9(2), 79-94. 